\title{
Pelatihan Metodologi Penelitian dan Penggunaan Aplikasi Software Statistika SPSS untuk Guru Yayasan Miftahul Ulum Timbuan Lamongan
}

\author{
Erna Hayati ${ }^{1}$, Diah Ayu Novitasari ${ }^{2}$, Laily Chodariyanti ${ }^{3}$ \\ ${ }^{1}$ Akuntansi, Fakultas Ekonomi, Universitas Islam Lamongan - Rangge, Lamongan \\ ${ }^{2}$ Manajemen, Fakultas Ekonomi, Universitas Islam Lamongan - Duduk Sampeyan, Gresik \\ ${ }^{3}$ Manajemen, Fakultas Ekonomi, Universitas Islam Lamongan - Jl. Veteran, Lamongan \\ E-mail: ernahayati84@gmail.com ${ }^{1}$, deeayunovitasari@gmail.com ${ }^{2}$, lailychodariyanti@gmail.com ${ }^{3}$.
} 085655409155

\begin{abstract}
ABSTRAK
Permasalahan yang dihadapi oleh guru Yayasan Miftahul Ulum Timbuan adalah kurangnya produktifitas dalam menghasilkan karya ilmiah atau penelitian. Kurangnya produktifitas membuat penelitian disebabkan karena kurang pemahaman tentang metodologi penelitian dan penguasaal aplikasi statistika yang dapat membantu mengolah data penelitian. Padahal menghasilkan atau membuat penelitian sangat penting untuk memenuhi kewajiban guru sebagai tenaga pendidik profesional. Hal inilah yang mendasari diadakannya Pelatihan Metodologi Penelitian dan Penggunaan Aplikasi Software Statistika SPSS Untuk Guru Yayasan Miftahul Ulum Lamongan dirancang agar dapat mengatasi permasalahan tersebut. Harapannya dengan adanya kegiatan pelatihan ini maka dapat memotivasi guru Yayasan Miftahul Ulum Timbuan untuk menghasilkan penelitian dan dapat mempublikasikan hasil penelitiannya dalam jurnal maupun forum ilmiah atau seminar ilmiah pendidikan. Kegiatan ini dilakukan dengan metode penyuluhan, pelatihan dan pendampingan. Kegiatan penyuluhan ditekankan pada pentingnya melakukan penelitian bagi guru untuk meningkatkan profesionalitasnya. Kegiatan ini meliputi pelatihan tentang metodologi penelitian dan penggunaan software SPSS dalam analisis data penelitian. Sedangkan kegiatan pendampingan dilakukan selama pelatihan agar guru terampil dalam menggunakan software SPSS.
\end{abstract}

Kata kunci : guru; metodologi; penelitian; SPSS.

\section{ABSTRACT}

The problem faced by Miftahul Ulum Timbuan Foundation teachers is the lack of productivity in producing scientific work or research. Lack of productivity makes research due to lack of understanding of research methodologies and the ruling of statistical applications that can help process research data. Though producing or making research is very important to fulfill the obligations of teachers as professional educators. This is what underlies the holding of the Research Methodology Training and the Use of SPSS Statistical Software Applications for Teachers of the Miftahul Ulum Lamongan Foundation designed to overcome these problems. It is hoped that the existence of this training activity will motivate the teachers of the Miftahul Ulum Timbuan Foundation to produce research and be able to publish their research findings in scientific journals or forums or educational scientific seminars. This activity is carried out with methods of counseling, training and mentoring. Counseling activities are emphasized on the importance of conducting research for teachers to improve their professionalism.

Cara Mengutip : Hayati, E., Novitasari, D. A., Chodariyanti, L. (2019). Pelatihan Metodologi Penelitian dan Penggunaan Aplikasi Software Statistika SPSS untuk Guru Yayasan Miftahul Ulum Timbuan Lamongan. JAST: Jurnal Aplikasi Sains dan Teknologi, 3 (2),129-134. doi:http://dx.doi.org/10.33366/jast.v3i2.1496 
This activity includes training on research methodology and the use of SPSS software in the analysis of research data. While the mentoring activities were carried out during the training so that the teacher was skilled in using SPSS software.

Keywords : teacher; method; research; SPSS.

\section{PENDAHULUAN}

Yayasan Miftahul Ulum Timbuan Lamongan merupakan salah satu yayasan yang bernaung dibawah lembaga pendidikan Ma'arif NU Lamongan. Yayasan yang telah berdiri sejak lama ini memiliki tiga sekolah yaitu MI (Madrasah Ibtidayah), MTs (Madrasah Tsanawiyah), MA (Madrasah Aliyah). Tiga sekolah ini masing-masing memiliki jumlah guru yang cukup banyak. Sebagian besar guru di Yayasan Miftahul Ulum sudah memiliki sertifikat pendidik dari program Pemerintah yakni sertifikasi Guru. Sertifikat pendidik yang dimiliki oleh Guru Yayasan mewajibkan adanya peningkatan profesionalisme Guru. Salah satu hal yang menandai adanya peningkatan profesionalisme Guru adalah meningkatnya kuantitas dan kualitas kegiatan pendidikan dan pelatihan yang diikuti, serta aktif di forum ilmiah. Namun selama ini hal tersebut masih menjadi hal yang ditakuti oleh para Guru. Terutama keaktifan Guru di forum ilmiah. Alasan utama yang menjadikan Guru kurang aktif di forum ilmiah adalah kurangnya pengetahuan akan pentingnya forum ilmiah dan pentingnya menghasilkan karya ilmiah atau penelitian.

Bagi sebagian besar guru menganggap bahwa penelitian bukanlah suatu kewajiban yang perlu dilakukan. Penelitian dianggap suatu hal yang sulit. Selain itu kurangnya pengetahuan tentang metodologi penelitian, teknik penulisan karya ilmiah dan penguasaan analisis data penelitian juga menjadi kendala yang dihadapi [1]. Padahal dengan kegiatan penelitian dapat meningkatkan kompetensi profesional para guru [2].

Hal inilah yang mendasari kegiatan pengabdian masyarakat yaitu Pelatihan Metodologi Penelitian dan Penggunaan Aplikasi Software Statistika SPSS Bagi Guru Yayasan Pendidikan Miftahul Ulum Timbuan Lamongan diusulkan. Tujuan utama dari kegiatan ini adalah meningkatkan keterampilan Guru Yayasan Miftahul Ulum Timbuan Lamongan dalam membuat penelitian dan menguasai penggunaan aplikasi statistika. Harapan dengan adanya kegiatan ini Guru Yayasan Miftahul Ulum Timbauan dapat memahami metodologi penelitian dan memiliki keterampilan menggunakan aplikasi Statistika sehingga dapat menghasilkan karya tulis ilmiah atau penelitian yang berkualitas. Penelitian yang berkualitas akan membuat Guru menjadi percaya diri untuk aktif di forum ilmiah dan mampu mempublikasikan hasil penelitiannya dalam jurnal.

\section{METODE KEGIATAN}

Pada dasarnya kegiatan pengabdian masyarakat ini berupa kegiatan pelatihan. Adapun metode pelaksanaan kegiatan dapat dilihat pada bagan berikut ini: 


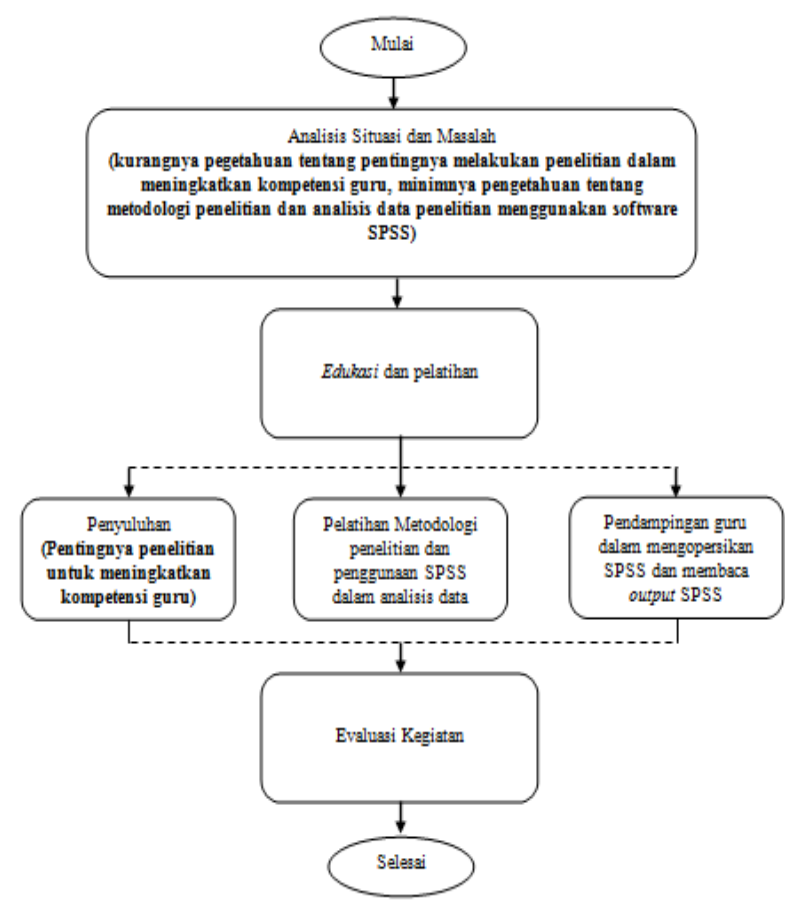

Gambar 1. Diagram Alir Pelaksanaan Kegiatan

Adapun tahapan kegiatan pelatihan ini, dapat dijelaskan sebagai berikut:

\section{Penyuluhan}

Langkah awal kegiatan ini yaitu mensosialisasikan kepada para guru berkenaan dengan tujuan program dan target yang ingin dicapai dalam program ini. Sosialisasi ini sangat penting dilakukan diawal agar tidak terjadi kesalahpahaman antara para guru dengan pelaksana, sehingga tujuan dari program ini bisa tercapai. Sosialisasi ini dilakukan dengan cara pemaparan dan diskusi tentang permasalahan yang dihadapi oleh guru dan solusi yang ditawarkan oleh pelaksana. Kemudian dilakukan penyuluhan tentang pentingnya seorang guru melakukan penelitian dan mempublikasikan karya ilmiahnya dalam rangka meningkatkan kompetensinya.

\section{Pelatihan}

Tahap ini, pelaksana memberikan pelatihan dengan materi metodologi penelitian dan Analisis data penelitian dengan menggunakan aplikasi software Statistika SPSS.

\section{Pendampingan}

Pada tahap pendampingan, para guru didampingi pada saat proses instalasi program dan praktek menggunakan SPSS.

4. Evaluasi Kegiatan

Tahap evaluasi kegiatan, pelaksana menyebarkan kuisioner umpan balik untuk mengetahui kepuasan guru terhadap pelatihan ini dan seberapa tingkat pemahaman guru terhadap materi yang sudah diberikan dalam pelatihan.

\section{KARYA UTAMA}

Kegiatan pelatihan metodologi penelitian dan penggunaan software Statistika SPSS bertujuan untuk meningkatkan pemahaman guru tentang metodologi penelitian dan penggunaan SPSS dalam analisis data penelitian, sehingga diharapkan dapat mendorong produktivitas dan kualitas penelitian yang dilakukan oleh guru Yayasan Miftahul Ulum Timbuan. Gambar 2 menunjukkan suasana pada saat kegiatan pelatihan berlangsung.

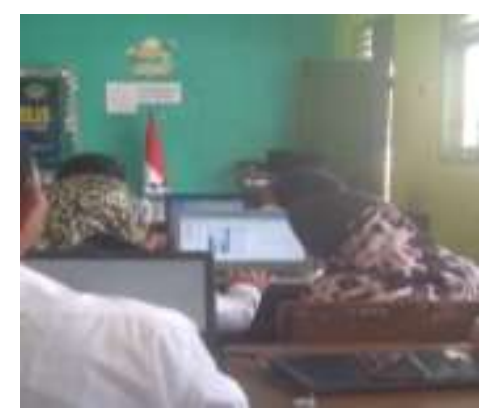

Gambar 2. Suasana Pelatihan 


\section{ULASAN KARYA}

Kegiatan pelatihan diawali dengan kegiatan penyuluhan. Dimana kegiatan penyuluhan ditekankan pada pentingnya fungsi penelitian bagi guru dan hambatan guru dalam melakukan penelitian. Setelah mitra memahami pentingnya melakukan penelitian, selanjutnya guru juga diberikan pemaparan tentang media yang digunakan untuk mempublikasikan hasil penelitian. Sehingga guru menyadari pentingnya fungsi penelitian untuk meningkatkan kompetensinya sebagai pendidik dan salah satu solusinya yaitu mengetahui bagaimana metode penelitian dan bagaimana analisis data penelitian yang tepat.

Pada sesi pelatihan, materi yang diberikan terkait metodologi penelitian dan analisis data penelitian menggunakan SPSS. Pada sesi materi tentang metodologi penelitian, materi lebih ditekankan pada metodologi penelitian tindakan kelas (PTK). Hal ini mengingat penelitian yang dilakukan oleh guru sebagian besar merupakan jenis pendekatan penelitian tindakan kelas (PTK), meskipun tidak menutup kemungkinan melakukan juga pendekatan yang lain.

Penelitian Tindakan Kelas (PTK) menurut Hopkins adalah kajian yang bersifat reflektif untuk meningkatkan kemantapan rasional dalam melaksanakan tugas dan memperdalam kondisi dalam praktik pembelajaran [3] Fungsi penelitian tindakan kelas (PTK) antara lain: (1) untuk melakukan perubahan atau peningkatan terhadap praktik pendidikan yang diteliti secara lebih langsung; (2) untuk menerapkan hasil penelitian melalui praktik langsung oleh guru di lapangan sehingga guru bisa memperbaiki kinerjanya bedasarkan hasil penelitiannya; (3) untuk mengembangkan profesionalitas sebagai pendidik dalam lingkup kerja [4].

Setelah materi tentang metodologi penelitian tindakan kelas disampaikan, materi pelatihan selanjutnya yaitu penggunaan aplikasi Statistika SPSS dalam analisis data penelitian. Dalam penelitian, proses analisis data merupakan hal yang sangat penting, agar data penelitian dapat lebih bermakna dan menghasilkan informasi. Metode dalam analisis data umumnya menggunakan metode statistika. Metode statistika terbagi menjadi dua yaitu statistika deskriptif dan statistika inferensia.

Penelitian tindakan kelas (PTK) merupakan penelitian kasus di suatu kelas, sehingga hasilnya tidak dapat digeneralisasikan ke kelas atau bahkan ke tempat yang lain. Oleh sebab itu, dalam analisis data PTK, data cukup dideskripsikan saja. Metode statistika yang tepat digunakan dalam analisis data PTK adalah metode statistika deskriptif, bukan inferensial [5]. Atas dasar hal tersebut, maka pada pelatihan penggunaan aplikasi SPSS, materi yang dipaparkan ditekankan pada bagaimana menganalisis data menggunakan metode statistika deskriptif. Tahap pendampingan dilakukan saat pelatihan penggunaan SPSS. Para guru diminta untuk mempraktekkan langsung materi yang sudah diberikan di laptop masing-masing. Pelaksana dibantu oleh mahasiswa untuk mendampingi guru baik saat menginstal software SPSS maupun pada saat mitra mengalami kendala selama kegiatan praktek menggunakan SPSS. 


\section{DAMPAK DAN MANFAAT KEGIATAN}

Dampak dari pelatihan ini bagi guru Yayasan Miftahul Ulum Timbuan adalah :

a. Meningkatnya pemahaman guru tentang pentingnya melakukan penelitian/karya ilmiah

b. Meningkatnya pengetahuan guru tentang bagaimana metode penelitian

c. Meningkatkan pengetahuan dan keterampilan guru dalam penggunaan SPSS sebagai alat bantu dalam analisis data penelitian

Manfaat yang diperoleh dari kegiatan pelatihan ini yaitu:

a. Guru Yayasan Miftahul Ulum Timbuan mengetahui pentingnya melakukan penelitian

b. Guru Yayasan Miftahul Ulum Timbuan mampu membuat penelitian yang berkualitas dengan metode penelitian dan penggunaan alat analisis data Statistika yang tepat.

c. Terbinanya hubungan yang baik antara perguruan tinggi dengan masyarakat dalam bentuk transfer ilmu pengetahuan.

\section{KESIMPULAN}

Berdasarkan hasil dari kegiatan pelatihan yang diadakan di Yayasan Miftahul Ulum Timbuan, dapat disimpulkan yaitu segenap guru di lingkungan Yayasan Miftahul Ulum Timbuan merasa sangat antusias dengan adanya pelatihan yang diselenggarakan dalam rangka meningkatkan kompetensi guru. Pelatihan ini mampu meningkatkan pengetahuan guru tentang metodologi penelitian dan analisis data penelitian menggunakan software SPSS.

\section{PENGHARGAAN}

Tim pelaksana kegiatan pengabdian masyarakat mengucapkan terima kasih kepada DRPM Kemenristekdikti yang telah memberikan dukungan berupa dana hibah Program Kemitraan Masyarakat Stimulus (PKMS) tahun anggaran 2019 sehingga pelatihan ini dapat terlaksana dengan baik. Tim pelaksana juga mengucapkan terima kasih kepada Rektor Universitas Islam Lamongan, LITBANG PEMAS, Dekan Fakultas Ekonomi, Ketua Yayasan Miftahul Ulum Timbuan dan seluruh Kepala Sekolah di lingkungan Yayasan Miftahul Ulum Timbuan yang telah mendukung kegiatan pengabdian masyarakat ini.

\section{DAFTAR PUSTAKA}

[1] Hasyim, M., Wisda, M.U., dan Dwi, S.R. (2017). "Pelatihan Metodologi Penelitian dan Pendampingan Penguasaan Aplikasi Statistika Software Open Source R dan SPSS Bagi Guru SMA". Seminar Nasional Hasil Pengabdian kepada Masyarakat (SENIAS), Madura, Universitas Islam Madura

[2] Sunarni. (2015). "Menumbuh kembangkan Budaya Riset dalam Mendukung Kompetensi Guru. Seminar Nasional Pengembangan Karir Pendidik Berbasis Karya 
Ilmiah". Malang, Fakultas Ilmu

Pendidikan Universitas Negeri

Malang

[3] Muslich, M. (2011). Melaksanakan

PTK Itu Mudah. Jakarta: Bumi

Aksara.

[4] Suparno, P. (2008). Riset Tindakan untuk Pendidik. Jakarta: Grasindo.

[5] Mill, Geoffrey E. (2000). Action Research: A Guide for The Teacher Researcher. New Jersey: Prentice Hall Inc. 